\title{
Simultaneous removal of a tumour of the right atrium and inferior vena cava and coronary bypass-grafting in a patient with recurrent clear renal cell carcinoma
}

\author{
Edward Pietrzyk ${ }^{1}$, Stanisław Głuszek ${ }^{2}$, Kamil Michta ${ }^{1}$, Iwona Gorczyca-Michta ${ }^{3}$, Marta Kot ${ }^{2}$, \\ Beata Wożakowska-Kapłon ${ }^{3,4}$ \\ ${ }^{1}$ Department of Cardiac Surgery, Świętokrzyskie Centre of Cardiology, Kielce, Poland \\ ${ }^{2}$ Clinical Department of Surgery, Regional Consolidated Hospital in Kielce, Poland \\ ${ }^{3} 1^{\text {st }}$ Clinical Department of Cardiology, Świętokrzyskie Centre of Cardiology, Kielce, Poland \\ ${ }^{4}$ Department of Health Sciences, Jan Kochanowski University in Kielce, Poland \\ Kardiochirurgia i Torakochirurgia Polska 2015; 12 (4): 348-350
}

\begin{abstract}
Metastatic cardiac tumours are the most common malignant cardiac tumours. In the early stages they are usually asymptomatic, but their consequences can be very serious, and the prognosis is poor. We present a patient with recurrent renal cell carcinoma as a tumour of the right atrium and the vena cava inferior in whom cancerous masses were removed with simultaneously coronary artery bypass-grafting.

Key words: cardiac tumour, renal clear cell carcinoma.
\end{abstract}

\section{Introduction}

The majority of malignant cardiac tumours are metastatic. Metastatic tumours are 20-40 times more frequent than primary tumours [1, 2], with the incidence of the latter estimated from $0.0017 \%$ to $0.02 \%$ [3]. Metastatic cardiac tumours most often originate from lung tumours (30-40\% of metastatic cardiac tumours), breast tumours (11\%), lymphomas (10\%), leukaemias (10\%), mesothelioma (9\%), oesophageal cancer $(6 \%)$, melanoma, gastric cancer, pancreatic cancer, renal cancer (3\% each), hepatic cancer, colorectal cancer, ovarian cancer, and prostate cancer (1\% each) $[4,5]$. The symptoms of metastatic cardiac tumours are usually non-specific, and the diagnosis is reached relatively late [6]. Periodic echocardiographic control is of paramount importance in patients treated for neoplastic disease because echocardiography is a primary non-invasive diagnostic method that allows physicians to reveal pathological intracardiac structures and implement further diagnostics and treatment.

\section{Case study}

The patient (aged 70 years, with stable angina pectoris, type 2 diabetes, after right-sided nephrectomy due to

\section{Streszczenie}

Guzy przerzutowe serca są najczęstszymi złośliwymi nowotworami serca. Początkowo przebiegają zwykle bezobjawowo, choć ich następstwa mogą być bardzo poważne, a rokowanie nie jest pomyślne. W pracy przedstawiono chorego ze wznową raka jasnokomórkowego nerki w postaci guza prawego przedsionka i żyły głównej dolnej, u którego wykonano jednocześnie usunięcie mas nowotworowych oraz pomostowanie aortalno-wieńcowe. Słowa kluczowe: guz serca, rak jasnokomórkowy nerki.

clear cell carcinoma) was referred to the cardiac surgery department in 2011 after non-invasive diagnostics to remove a tumour of the right atrium and inferior vena cava. After the nephrectomy, the patient felt well and did not restrict his everyday activities. An outpatient echocardiographic examination (performed two years after the nephrectomy) revealed a solid structure $48 \times 31 \mathrm{~mm}$ in size (apical fourchamber projection) in the inferior vena cava and right atrium, protruding into the tricuspid opening, with substantial tricuspid valve insufficiency (Fig. 1). The examination also revealed hypokinesia of the apex and apical segments of the adjoining walls as well as reduced left ventricular ejection fraction (40\%). The patient was referred for further diagnostics: positron emission tomography of the abdominal cavity revealed local recurrence of clear cell renal carcinoma and infiltration of the inferior vena cava below the diaphragm. Due to the planned sternotomy and laparotomy, coronary angiography was performed: the examination demonstrated the presence of critical stenoses in the circumflex branch, the marginal branch, and the anterior interventricular branch. The mortality risk associated with the cardiac surgical procedure was $1.56 \%$ (according

Address for correspondence: dr n. med. Iwona Gorczyca-Michta, $1^{\text {st }}$ Clinical Department of Cardiology, Świętokrzyskie Centre of Cardiology, 45 Grunwaldzka St., 25-637 Kielce, phone: +48 604407 956, e-mail: iwona.gorczyca@interia.pl 
to EuroSCORE II). The patient was operated on in general hypothermia $25^{\circ} \mathrm{C}$ using extracorporeal circulation, selective CNS perfusion, and cardioplegia. After the abdominal cavity was opened, dissection of the post-nephrectomy space and the inferior vena cava was performed; a locally advanced tumour was found, bulging the inferior vena cava and infiltrating the pancreas and the duodenum. The brachiocephalic artery, superior vena cava, and right atrium were cannulated. After achieving $25^{\circ} \mathrm{C}$ hypothermia and employing selective cerebral perfusion, the vessels of the aortic arch were clamped and the inferior vena cava and the right atrium were opened (Fig. 2). The tumour was removed completely from the right atrium (RA) and inferior vena cava (IVC), which restored normal flow between the IVC and RA (Fig. 3). Due to its advancement, the local tumour recurrence was not removed. Subsequently, three venous bypasses were implanted into the circumflex branch, the marginal branch, and the anterior interventricular branch. The postoperative course was uneventful. Histopathological examination of the tumour demonstrated recurrence of clear cell renal carcinoma. The patient was discharged from the ward on the ninth postoperative day and was referred for further oncological treatment.

\section{Discussion}

The presented case is a rare example of a secondary tumour occurring in the cardiac chambers in the course of
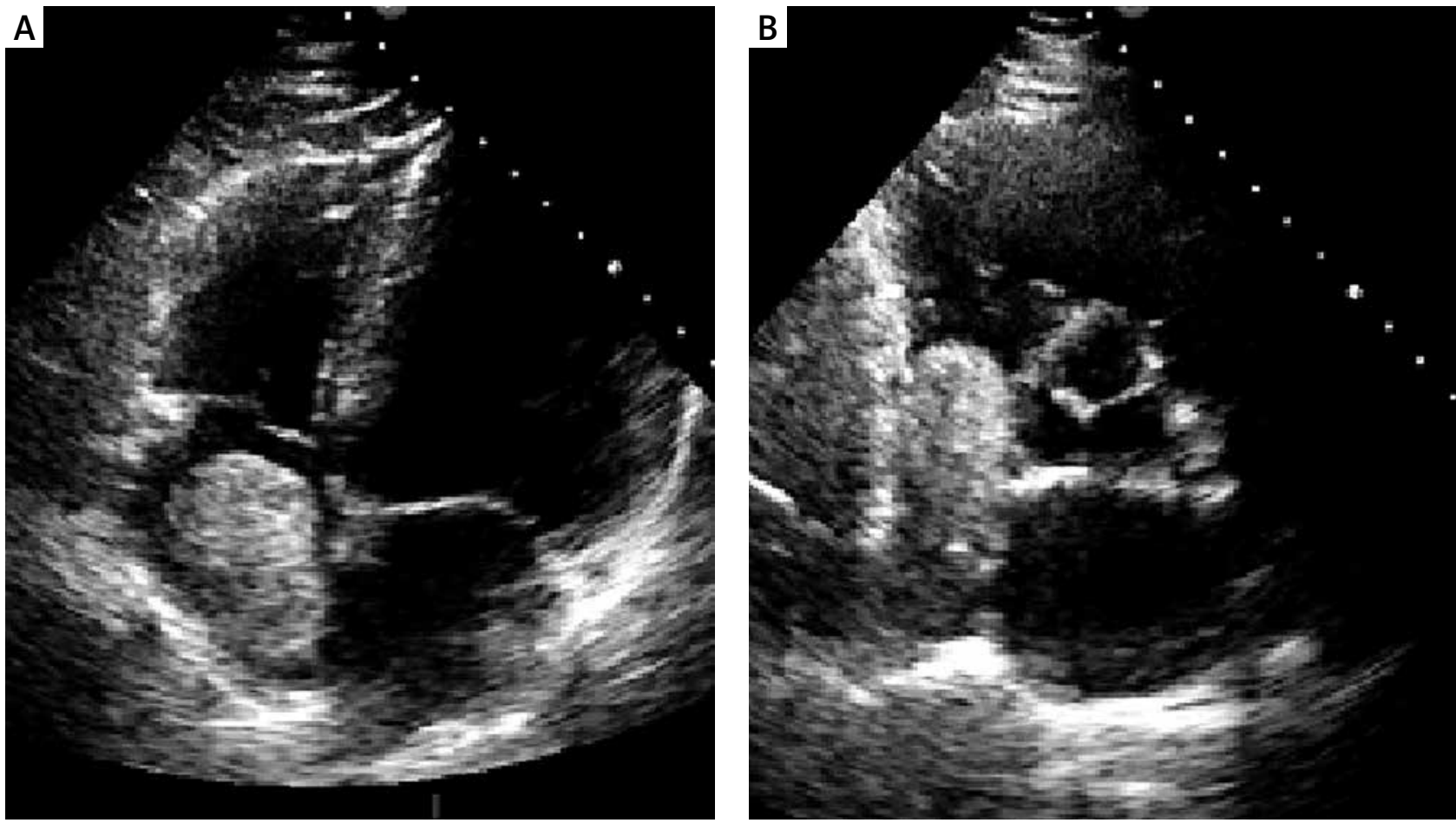

Fig. 1. Echocardiographic examination - tumour of the right atrium in apical four-chamber view (left side) and in parasternal short axis view at the level of the aortic valve (right side)

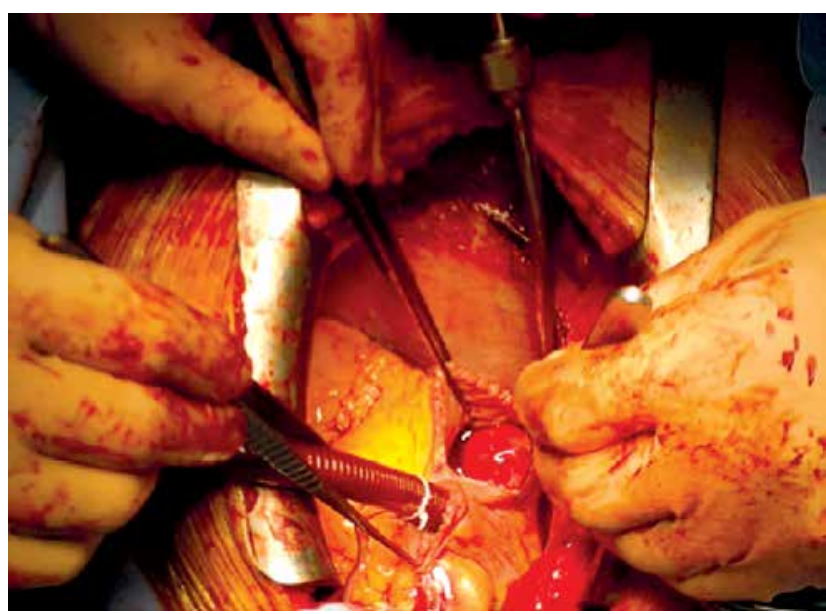

Fig. 2. Intraoperative image - the tumour after the opening of the right atrium

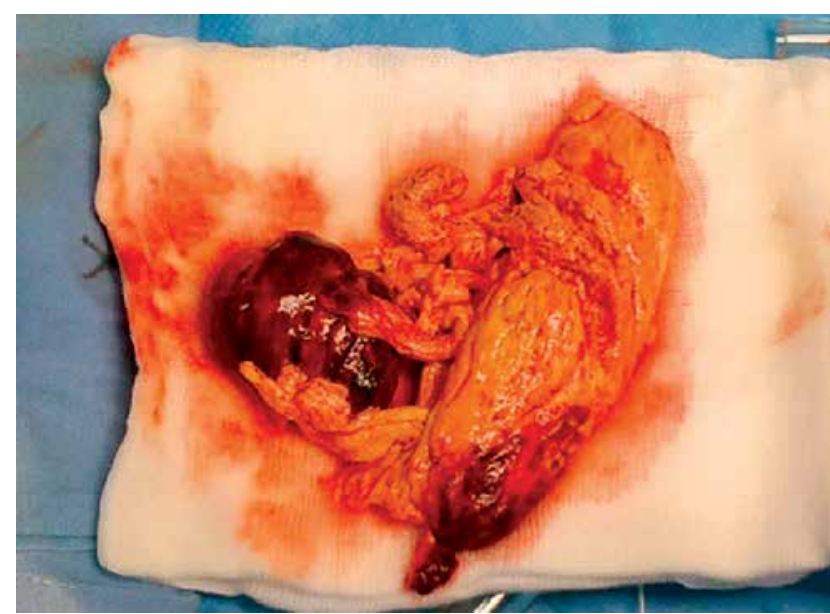

Fig. 3. The tumour removed from the right atrium and inferior vena cava 
clear cell renal carcinoma. The structures most often found in the cardiac chambers are non-neoplastic lesions, such as thrombi or bacterial vegetations, followed by secondary neoplastic lesions and primary tumours (benign and malignant). Dąbek et al. [7] observed the occurrence of metastatic cardiac tumours in $17 \%$ of cardiac tumour patients who were included in the register during seven years of observations; however, no tumours originating from clear cell renal carcinoma were observed. In the presented patient the tumour filled a substantial part of the right atrium and protruded into the tricuspid opening but did not cause any particular ailments. Cardiac tumours are asymptomatic for long periods of time and are thus usually diagnosed by chance. The symptoms depend on tumour location, dimensions, mobility, and malignancy. The ailments are usually non-specific and take the form of heart failure or cardiac dysrhythmias. When performing a physical examination, one can note a murmur dependent on the location of the tumour as well as a variability of the auscultatory phenomena dependent on the patient's body position. Cardiac tumours can also manifest as recurrent thromboembolic episodes. Metastatic cardiac tumours manifesting as cardiac tamponade have also been described [8]. The advancement of the neoplastic lesions in our patient was confirmed with tomography and positron emission tomography. However, the first diagnostic tool that was used was an echocardiographic examination, which was performed two years after the nephrectomy. It seems that this simple, easily available, and relatively inexpensive examination should be performed in all patients after oncological treatment. Although tumours metastasize to the heart in approximately 5-14.2\% of cases, their early diagnosis enables the implementation of measures aimed at preventing dramatic cardiac tumour complications such as embolisms, closure of atrioventricular or valvular openings, or dangerous ventricular cardiac dysrhythmias [9]. The number of patients with cardiac metastases increases with the constant rise in the number of patients with neoplasms, so the number of oncological patients that can benefit from cardiac diagnostics is growing [10]. In the presented patient, coronary angiography was performed before the scheduled procedure; the examination revealed multivessel atherosclerosis, and concurrent coronary artery bypass grafting was planned. Doppler ultrasound of the carotid arteries was also performed, revealing no significant lesions in the carotid arteries. The prognosis for patients with metastatic cardiac tumours is unfavourable. The time of survival usually does not exceed one year from the diagnosis [11]. Due to the extent of the surgery, anastomosis between the left internal thoracic artery and the anterior interventricular branch of the left coronary artery was abandoned, and three venous bypasses were performed. Despite the extent of the procedure, the postoperative course was uneventful.

The patient was operated on by a multispecialist team including cardiac and oncological surgeons. The surgery was preceded by extensive diagnostics and numerous consultations (oncological, cardiac, diabetic, psychiatric). The recurrence of the clear cell renal carcinoma visualised by positron emission tomography did not give grounds for a prognosis of complete recovery; however, the cardiac surgical intervention undertaken before the occurrence of the tumour's symptoms saved the patient from its dramatic complications.

\section{Disclosure}

Authors report no conflict of interest.

\section{References}

1. Abraham K, Reddy V, Gattuso P. Neoplasms metastatic to the heart: review of 3314 consecutive autopsies. Am J Cardiovasc Pathol 1990; 3: 195-198.

2. Kutalek S, Panidis I, Kotler M, Mintz GS, Carver J, Ross JJ. Metastatic tumors of the heart detected by two-dimensional echocardiography. Am Heart J 1985; 109: 343-349.

3. Silverman N. Primary cardiac tumors. Ann Surg 1980; 191: 127-138.

4. Bussani R, De-Giorgio F, Abbate A, Silvestri F. Cardiac metastases. J Clin Pathol 2007; 60: 27-34.

5. Reynen K, Köckeritz U, Strasser RH. Metastases to the heart. Ann Oncol 2004; 15: 375-381.

6. Shapiro LM. Cardiac tumours: diagnosis and management. Heart 2001; 85 : 218-222.

7. Dąbek J, Twardowski R, Jakubowski D, Michniak B, Świderski R, Gąsior Z. Skuteczność leczenia guzów serca rozpoznanych w klinice kardiologii w siedmioletniej obserwacji. Pol Merkuriusz Lek 2009; 161: 362-367.

8. Lisowska A, Knapp M, Sobkowicz B, Kozieradzka A. Metastatic malignant cardiac tumour - a case report. Kardiol Pol 2010; 68: 1402-1403.

9. Bussani R, De-Giorgio F, Abbate A, Silvestri F. Cardiac metastases. J Clin Pathol 2007; 60: 27-34.

10. Al-Mamgani A, Baartman L, Baaijens M, de Pree I, Incrocci L, Levendag PC. Cardiac metastases. Int J Clin Oncol 2008; 13: 369-372.

11. Pruszczyk P, Styczynski G. Nowotwory serca. In: Choroby wewnętrzne. Szczeklik A (ed.). Vol. I. Medycyna Praktyczna, Kraków 2013; 377-378. 